\title{
Behavioral Inhibition and Dual Mechanisms of Anxiety Risk: Disentangling Neural Correlates of Proactive and Reactive Control
}

Emilio A. Valadez ${ }^{1}$, Sonya V. Troller-Renfree ${ }^{2}$, George A. Buzzell ${ }^{3}$, Heather A. Henderson ${ }^{4}$, Andrea Chronis-Tuscano ${ }^{5}$, Daniel S. Pine ${ }^{6}$, and Nathan A. Fox ${ }^{1}$

${ }^{1}$ Department of Human Development and Quantitative Methodology, University of Maryland, College Park

${ }^{2}$ Department of Biobehavioral Sciences, Teachers College, Columbia University

${ }^{3}$ Department of Psychology, Florida International University

${ }^{4}$ Department of Psychology, University of Waterloo

${ }^{5}$ Department of Psychology, University of Maryland, College Park

${ }^{6}$ Emotion and Development Branch, National Institute of Mental Health Intramural Research Program, National Institute of Mental Health 
medRxiv preprint doi: https://doi.org/10.1101/2020.12.01.20242123; this version posted December 2, 2020. The copyright holder for this preprint (which was not certified by peer review) is the author/funder, who has granted medRxiv a license to display the preprint in perpetuity.

It is made available under a CC-BY-NC-ND 4.0 International license .

Abstract
Background: Behavioral inhibition (BI) is a temperament style characterized by heightened reactivity and negative affect in response to novel people and situations, and it is a strong predictor of anxiety problems later in life. However, not all BI children develop anxiety problems and mounting evidence suggests that how one manages their cognitive resources (cognitive control) influences anxiety risk. The present study tests whether more (proactive control) or less (reactive control) planful cognitive strategies moderate relations between BI and anxiety. Methods: Participants included 144 adolescents (55.9\% female) whose temperament was assessed during toddlerhood. In adolescence $\left(M_{\text {age }}=15.4\right.$ years), participants completed an AX Continuous Performance Test while EEG was recorded in order to disentangle neural activity related to proactive (cue-locked P3b) and reactive (probe-locked N2) control. Results: BI was associated with greater total anxiety scores only among adolescents with smaller $\Delta \mathrm{P} 3 \mathrm{bs}$ and larger $\Delta \mathrm{N} 2 \mathrm{~s}$ - a pattern consistent with decreased reliance on proactive strategies and increased reliance on reactive strategies. Additionally, a larger $\Delta \mathrm{P} 3 \mathrm{~b}$ was associated with greater total anxiety scores. Conclusions: BI relates to risk for anxiety specifically among adolescents who rely less on proactive strategies and more on reactive control strategies. Results further suggest that proactive control differentiates a BI-related etiological pathway to anxiety from a more general pathway to anxiety occurring regardless of BI level. Thus, developmental context (i.e., temperament) moderates the association between anxiety and proactive control. The present study is the first to characterize how proactive and reactive control uniquely relate to pathways toward anxiety risk.

Keywords: anxiety, cognitive control, behavioral inhibition, EEG, adolescence. 
medRxiv preprint doi: https://doi.org/10.1101/2020.12.01.20242123; this version posted December 2 , 2020. The copyright holder for this preprint (which was not certified by peer review) is the author/funder, who has granted medRxiv a license to display the preprint in perpetuity.

It is made available under a CC-BY-NC-ND 4.0 International license .

Behavioral Inhibition and Dual Mechanisms of Anxiety Risk: Disentangling Neural Correlates of

\section{Proactive and Reactive Control}

Behavioral inhibition (BI) is a temperament style characterized by heightened reactivity and negative affect in response to novel people and situations (Kagan et al., 1984). Bl is among the strongest predictors of later-life anxiety problems (Fox et al., 2005; Fox \& Pine, 2012; Schwartz et al., 1999), especially when BI is stable throughout infancy and early childhood (Chronis-Tuscano et al., 2009). Nevertheless, $30-60 \%$ of toddlers with BI do not go on to meet criteria for an anxiety disorder during childhood or adolescence (Clauss \& Blackford, 2012; Gladstone et al., 2005). Thus, identifying factors that moderate the relations between $\mathrm{BI}$ and anxiety remain a key issue for prevention and intervention.

Mounting evidence finds cognitive control, including use of specific cognitive control strategies, may be a marker of anxiety risk for children with BI (Henderson, 2010; Lamm et al., 2014; McDermott et al., 2009; Smith et al., 2019; Troller-Renfree et al., 2019). Dual-mechanisms of control theory (Braver, 2012) differentiates two temporally distinct and complementary, yet largely independent strategies of cognitive control: proactive and reactive. Proactive control involves early selection and maintenance of goal-relevant information, such as the biasing of attention toward stimulus color rather than the content of the word on the color-word Stroop task. Reactive control involves as-needed capacities, often in response to conflict, such as conflict between the color and word content on an incongruent Stroop stimulus, or conflict between the response that was made and the response that should have been made. During the first decade of life, children tend to shift from greater reliance on reactive control to greater reliance on proactive control (Lucenet \& Blaye, 2014; Troller-Renfree et al., 2020). Afterwards, proactive control continues to grow in efficiency throughout adolescence and young adulthood (Chevalier et al., 2015).

A longitudinal study examining cognitive control factors in the context of $\mathrm{Bl}$-anxiety relations revealed that children high in $\mathrm{BI}$ during toddlerhood tended to use a relatively more reactive than 
medRxiv preprint doi: https://doi.org/10.1101/2020.12.01.20242123; this version posted December 2, 2020. The copyright holder for this preprint (which was not certified by peer review) is the author/funder, who has granted medRxiv a license to display the preprint in perpetuity. It is made available under a CC-BY-NC-ND 4.0 International license .

proactive control strategy than children low in BI during an AX continuous performance test (AX-CPT) administered at age 13 years (Troller-Renfree et al., 2019). Moreover, the type of cognitive control strategy moderated the relations between $\mathrm{BI}$ and parent-reported anxiety such that children with high $\mathrm{BI}$ who used a more reactive control strategy had greater total anxiety at age 13 than children with BI who used a more proactive control strategy (Troller-Renfree et al., 2019). Additional support for the idea that children high in both $\mathrm{BI}$ and anxiety utilize more in-the-moment type strategies comes from studies showing increased performance on tasks necessitating conflict detection (Thorell et al., 2004; TrollerRenfree et al., 2019; White et al., 2011). Yet, more confirmatory evidence is lent by studies showing increased neural recruitment in high-conflict scenarios (event-related potential; ERPs) by children high in BI. Specifically, relative to youth with BI who are less anxious, youth high in both $\mathrm{BI}$ and anxiety have larger P3 responses to novel auditory tones (Reeb-Sutherland et al., 2009), larger N2 responses to conflict (Henderson, 2010; Lamm et al., 2014), and larger error-related negativity (ERN) responses to errors (McDermott et al., 2009), with one study showing that among children with BI, a larger ERN at age 7 prospectively predicted social anxiety symptoms at age 9 (Lahat et al., 2014; but see also Buzzell et al., 2017). The bulk of ERP evidence suggests that children with BI who engage in reactive control more may be at greater risk for anxiety difficulties than children with BI who use a less reactive-like control strategy.

Despite an extant literature focusing on reactive control, no studies examining BI to date have tried to characterize a neural measure of proactive control. This, coupled with the fact that proactive and reactive control processes are thought to be relatively independent (Braver, 2012; Gonthier et al., 2016), leaves it unclear whether the association between BI and anxiety depends purely on the level of reactive control (independent of proactive control) or whether proactive control also plays a critical role in the relations among $\mathrm{BI}$ and anxiety. To answer these questions, participants enrolled as part of a longitudinal study were assessed for BI during toddlerhood and completed an AX-CPT task modified for 
medRxiv preprint doi: https://doi.org/10.1101/2020.12.01.20242123; this version posted December 2 , 2020. The copyright holder for this preprint (which was not certified by peer review) is the author/funder, who has granted medRxiv a license to display the preprint in perpetuity.

It is made available under a CC-BY-NC-ND 4.0 International license .

EEG compatibility at age 15 years. Importantly, the present study utilized separate neural measures of proactive and reactive control in order to test whether behavioral findings from an earlier time point of this longitudinal study (Troller-Renfree et al., 2019) were driven mainly by proactive control, by reactive control, or by both. Given the 13-year behavioral finding that BI is associated with anxiety among youth who employ a relatively more reactive than proactive strategy on the AX-CPT (Troller-Renfree et al., 2019), it was hypothesized that, in this new 15 -year EEG assessment, BI would be associated with anxiety specifically when proactive control is low and reactive control is high.

\section{Materials and Methods}

\section{Participants}

Participants included 175 adolescents aged $15-17$ years who were administered an AX-CPT task during EEG recording as part of a longitudinal study examining the relations between infant temperament and the emergence of anxiety. This study's recruitment strategy and screening methods have been described in detail elsewhere (Hane et al., 2008). Briefly, 779 infants (age 4 months) completed a laboratory temperament screening for emotional and motor reactivity towards novel auditory and mobile stimuli. From these, infants with high motor and high positive or high negative reactivity were oversampled to reflect a range of temperamental reactivity that is wider than would be found in a randomly selected community sample. The selected infants $(n=291)$ continued to participate in assessments of cognitive and socio-emotional development throughout childhood and adolescence.

Informed consent and assent (as appropriate) were obtained at each assessment, and each visit protocol was approved by the institutional review board of the University of Maryland, College Park.

\section{Behavioral Inhibition}

Replicating the methods used in our previous investigation (Troller-Renfree et al., 2019), BI was assessed at ages 24 and 36 months. Behavioral coding of laboratory assessments (Calkins et al., 1996; Fox et al., 2001) and maternal report of social fear (using the Toddler Behavior Assessment 
medRxiv preprint doi: https://doi.org/10.1101/2020.12.01.20242123; this version posted December 2, 2020. The copyright holder for this preprint (which was not certified by peer review) is the author/funder, who has granted medRxiv a license to display the preprint in perpetuity. It is made available under a CC-BY-NC-ND 4.0 International license .

BI AND DUAL MECHANISMS OF ANXIETY RISK

Questionnaire) were standardized and then averaged together to create a BI composite score, based on the assumption that combining data from different informants, contexts, and ages reflects a more comprehensive assessment of the child's temperament (Lahat et al., 2014; Lamm et al., 2014; Walker et al., 2014).

\section{AX Continuous Performance Task}

To measure distinct neural indices of proactive and reactive control, participants completed an AX-CPT (Barch et al., 1997; Braver, 2012; Cohen et al., 1999) that was modified for simultaneous EEG recording. The AX-CPT presents a continuous series of letter pairs (i.e., a cue letter followed by a probe letter) dissociated into 4 trial types: $\mathrm{AX}, \mathrm{AY}, \mathrm{BX}$, and $\mathrm{BY}$. $\mathrm{AX}$ trials were the target trials, meaning that when participants saw an " $A$ " cue followed by an " $X$ " probe, they were to press a different button in response to the probe than during the other 3 trial types. Specifically, participants were instructed to press " 1 " following every cue, as well as most probe types, with the exception of an " $\mathrm{X}$ " probe that was preceded by an " $A$ " cue; in this case, participants were to press a " 4 ". Consistent with past ERP studies involving the $\mathrm{AX}-\mathrm{CPT}$, the traditional 70\%/10\%/10\%/10\% trial breakdown (reflecting $\mathrm{AX} / \mathrm{AY} / \mathrm{BX} / \mathrm{BY}$ trials) was modified to $55 \% / 15 \% / 15 \% / 15 \%$ in order to increase trial counts necessary to achieve adequate ERP signal-to-noise ratio (Lamm et al., 2013; Troller-Renfree, 2018). Participants completed a total of 319 trials (175/48/48/48) presented in random order. Letter stimuli were presented in boldface 60-point Courier New font on a black background. To make clear the distinction between cues and probes, cues were presented in cyan and probes were presented in white. Each trial began with a center fixation cross, followed by the cue stimulus which was presented for $500 \mathrm{~ms}$. The cue stimulus was followed by a randomized interstimulus interval of $1400-1600 \mathrm{~ms}$ (fixation cross). The probe was also presented for $500 \mathrm{~ms}$, with a response window of 1000 ms starting from probe onset. Stimuli were presented on a 17inch LCD monitor using E-Prime 2.0 Professional (Psychology Software Tools, Inc., Sharpsburg, PA). 
medRxiv preprint doi: https://doi.org/10.1101/2020.12.01.20242123; this version posted December 2 , 2020. The copyright holder for this preprint (which was not certified by peer review) is the author/funder, who has granted medRxiv a license to display the preprint in perpetuity.

It is made available under a CC-BY-NC-ND 4.0 International license .

Consistent with past work, individual trials were excluded from analysis if reaction time (RT) was >3 standard deviations above or below each participant's mean RT on correct trials (Troller-Renfree et al., 2019), resulting in exclusion of less than $3 \%$ of all trials $(M=2.92 \%, S D=0.01 \%)$. After excluding outlier trials, accuracy and mean reaction times were computed for each trial type. Consistent with other studies with children, participants were excluded from analyses if they had less than $60 \%$ accuracy on BY trials ( $n=2)$ (Troller-Renfree et al., 2019, 2020), which are the easiest trials because the B cue and Y probe signal totally redundant information. $d^{\prime}$ context, a commonly used behavioral index based on signal detection theory, provides a measure of the ability to discriminate between target and nontarget trials as a function of the cue (Cohen et al., 1999). $d^{\prime}$ context scores were computed by comparing correct responses on AX trials (hits) relative to incorrect responses on BX trials (false alarms). A correction was applied in cases where there was a hit rate of 1 (hit rate $=2^{-(1 / N)}$, where $\mathrm{N}=$ number of target trials) or a false alarm rate of 0 (false alarm rate $=1-2^{-(1 / N)}$, where $\mathrm{N}=$ number of nontarget trials). The distribution of $d^{\prime}$ context scores (skewness -0.09 , kurtosis 2.49 ) was inspected and determined to be normal. Consistent with the broader literature involving $d^{\prime}$ context, higher scores were interpreted to indicate a more proactive style of cognitive control because the participant used the cue information to inform future responses, whereas lower scores indicate a relatively more reactive style of control because the cue information was less motivationally salient to the participant (Cohen et al., 1999; Troller-Renfree et al., 2019, 2020).

\section{Screen for Child Anxiety Related Emotional Disorders}

Each participant and their parent completed the revised version of the Screen for Child Anxiety Related Emotional Disorders (SCARED) (Monga et al., 2000) at the 15-year assessment. The parent and child versions of the SCARED consist of 41 items presented on a 3-point Likert scale $(0=$ never/hardly ever true, 1 = sometimes/somewhat true, 2 = very/often true). Total anxiety scores were the primary outcome of interest. In order to combine information from multiple informants while also accounting 
medRxiv preprint doi: https://doi.org/10.1101/2020.12.01.20242123; this version posted December 2 , 2020. The copyright holder for this preprint (which was not certified by peer review) is the author/funder, who has granted medRxiv a license to display the preprint in perpetuity. It is made available under a CC-BY-NC-ND 4.0 International license .

for differences in how parents and children rate anxiety symptoms (Bowers et al., 2020), total anxiety scores were computed separately for parent and child, Z-transformed, and then averaged together to form an anxiety composite score for analyses (for separate regression results involving child-reported or parent-reported anxiety, see Supplementary Tables S1-S4).

\section{Electrophysiological Recording, Pre-processing, and Analysis}

Continuous EEG was recorded using a 128-channel Geodesic Sensor Net (Electrical Geodesics, Inc., Eugene, OR) and sampled at $250 \mathrm{~Hz}$. Before data collection, all electrode impedances were reduced to $<50 \mathrm{k} \Omega$. During data collection, electrodes were referenced to electrode Cz. All pre-processing, including ocular artifact detection and removal, was performed with the Maryland Analysis of Developmental EEG (MADE) pipeline (Debnath et al., 2020), which utilizes MATLAB (The MathWorks, Natick, MA) functions from EEGLAB (Delorme \& Makeig, 2004) and its plugins "FASTER" (Nolan et al., 2010), “ADJUST" (Mognon et al., 2011), and “ADJUSTED ADJUST” (Leach et al., 2020). Offline, data were re-referenced to an average reference and band-pass filtered from 0.3 to $50 \mathrm{~Hz}$ with a digital FIR filter. Data were segmented separately for each of the four trial types (i.e, AX, AY, BX, BY). Only trials with correct behavioral responses were analyzed. Channels were marked bad if voltage exceeded $\pm 150 \mu \mathrm{V}$, and any epochs in which more than $10 \%$ of non-ocular channels exceeded this threshold were marked bad; otherwise, bad channels were interpolated via a spherical-spline interpolation. Participants were only included in subsequent analyses if they had at least 10 artifact-free trials of each of the four trial types $\left(\mathrm{n}=144 ; M_{\text {age }}=15.4\right.$ years, $S D_{\text {age }}=0.6 ; 55.9 \%$ female). Remaining EEG processing steps were performed with a combination of custom MATLAB scripts and the FieldTrip Toolbox (Oostenveld et al., 2010). A Laplacian transform was applied to convert epoch data from $\mu \mathrm{V}$ to $\mathrm{V} / \mathrm{m}^{2}$ (i.e., current source density), thus improving spatial resolution (Tenke \& Kayser, 2012). In line with previous ERP work involving the AX-CPT, analysis focused on the cue-locked P3b and the probe-locked N2 (van Wouwe et al., 2011). All ERPs were aligned to a baseline of -200 to $0 \mathrm{~ms}$ with respect to stimulus onset. Each ERP 
medRxiv preprint doi: https://doi.org/10.1101/2020.12.01.20242123; this version posted December 2, 2020. The copyright holder for this preprint (which was not certified by peer review) is the author/funder, who has granted medRxiv a license to display the preprint in perpetuity.

It is made available under a CC-BY-NC-ND 4.0 International license .

component was scored by identifying the positive (in the case of the P3b) or negative (in the case of the N2) peak within the scoring window and averaging the amplitude from $40 \mathrm{~ms}$ (i.e., 10 sample points) pre-peak to $40 \mathrm{~ms}$ post-peak. This adaptive mean scoring approach was used because it is more robust to potential individual differences in peak latency than averaging across the entire scoring window, while still representing an efficient estimation of the true ERP amplitude (Clayson et al., 2013). Sensors for the centroparietal (P3b) and frontocentral (N2) regions-of-interest were selected based on the topography of the grand average waveforms, and the scoring time windows (described below) corresponded to the latencies between which the grand average waveforms exceeded approximately half the peak amplitude (van Wouwe et al., 2011).

\section{P3b}

The cue-locked P3b was used as the measure of proactive control. Previous work has shown that the B-cue minus A-cue P3b difference score significantly mediates the relationship between children's working memory abilities and their preference for a more proactive (versus reactive) behavioral strategy during the AX-CPT (Troller-Renfree et al., 2020). The P3b was measured within a time window of 430 to 680 ms post-cue after averaging across centroparietal sensor sites (E31, E54, E55, E79, and E80). Analyses focused on the difference between B and A cues ( $\triangle \mathrm{P} 3 \mathrm{~b}$ ) (Troller-Renfree et al., 2020; van Wouwe et al., 2011).

N2

The probe-locked N2 was used as the measure of reactive control. A 2-Hz high-pass filter was applied to probe-locked epochs in order to reduce the influence of the probe-locked P3b on the N2 (van Wouwe et al., 2011). The N2 was measured within a time window of 260 to 350 ms post-cue after averaging across frontocentral sensor sites (E5, E6, E7, E12, E13, E106, and E112). In line with the $d^{\prime}$ context behavioral measure of cognitive control strategy, analyses of the probe-locked N2 focused on 
medRxiv preprint doi: https://doi.org/10.1101/2020.12.01.20242123; this version posted December 2 , 2020. The copyright holder for this preprint (which was not certified by peer review) is the author/funder, who has granted medRxiv a license to display the preprint in perpetuity.

It is made available under a CC-BY-NC-ND 4.0 International license .

the difference between $A X$ and $B X$ trials $(\Delta N 2)$, indicating the extent to which participants discriminated between target and nontarget probes as a function of the cue (Cohen et al., 1999).

\section{Data Analytic Strategy}

To assess whether proactive and reactive control moderated the relations between $\mathrm{BI}$ and anxiety, two linear regression models were tested in R (version 3.6.2) with the function "Im". The outcome variable in both models was parent- and child-reported total anxiety from the SCARED, which, as noted earlier, were Z-transformed and then averaged together to create a composite total anxiety score. The first model was included as a partial replication of our previous investigation (Troller-Renfree et al., 2019). The model included $\mathrm{BI}, d^{\prime}$ context (as a behavioral measure of proactive vs. reactive control), and their interaction as predictors. In the second model, predictors included $B I, \Delta P 3 b, \Delta N 2$, and their two- and three-way interactions. Outliers were excluded from all between-subjects analyses if they were $>3$ standard deviations from the sample mean on the variable being tested, and all predictors were mean centered prior to the computation of interaction terms. Simple slopes from interactions were probed with Johnson-Neyman tests (Johnson \& Neyman, 1936) with robust standard error estimation using the "sim_slopes" function as part of the R package "interactions" (Long, 2019).

\section{Results}

\section{Task Behavior}

\section{Within-Subjects}

Descriptive statistics and bivariate correlations for key variables of interest are presented in Table 1. A one-way analysis of variance (ANOVA) revealed a significant within-subjects effect of trial type on correct-trial probe $\operatorname{RT}\left(F(3,572)=254.10, \eta^{2}=.57, p<.001\right)$. Post hoc tests revealed that all trial types were different from each other in terms of RT (all ps <.05). Specifically, probe RTs were fastest during $B X$ trials $(M=287 \mathrm{~ms}, S D=100 \mathrm{~ms})$, followed by BY $(M=293 \mathrm{~ms}, S D=100 \mathrm{~ms}), A X(M=340 \mathrm{~ms}$, $S D=83 \mathrm{~ms})$, and $A Y(M=452 \mathrm{~ms}, S D=95 \mathrm{~ms})$. 
medRxiv preprint doi: https://doi.org/10.1101/2020.12.01.20242123; this version posted December 2, 2020. The copyright holder for this preprint (which was not certified by peer review) is the author/funder, who has granted medRxiv a license to display the preprint in perpetuity. It is made available under a CC-BY-NC-ND 4.0 International license .

A similar one-way ANOVA revealed a significant within-subject effect of trial type on accuracy $\left(F(3,572)=170, \eta^{2}=.47, p<.001\right)$. Post hoc tests revealed that all trial types were different from each other (all ps <.05). BY trials were most accurate $(M=96.9 \%, S D=4.4 \%)$, followed by $B X(M=93.4 \%, S D$ $=7.9 \%), A X(M=92.0 \%, S D=5.3 \%)$, and $A Y(M=75.7 \%, S D=13.8 \%)$. Consistent with past studies of the AX-CPT in populations relying on proactive control, AY trials were the slowest and least accurate of all the trial types.

\section{Between-Subjects}

The results of the regression model involving $d^{\prime}$ context are presented in Table 2. There were no significant main effects of $\mathrm{BI}$ or $d^{\prime}$ context and no significant interaction effect (all $p s>.05$ ).

\section{EEG}

\section{Within-Subjects}

For grand average cue- and probe-locked ERPs, see Figure 1. Cue-locked P3B amplitude was significantly more positive following B cues than following A cues $(t(143)=9.51, d=0.79, p<.001)$. A one-way ANOVA revealed a significant within-subjects effect of trial type on probe-locked N2 amplitude $\left(F(3,572)=44.38, \eta^{2}=.19, p<.001\right)$. Post hoc tests revealed that all trial types significantly differed from each other in terms of $\mathrm{N} 2$ amplitude $(p s<.01)$ with the exception of $\mathrm{AX}$ and $\mathrm{BY}(p=.654)$.

\section{Between-Subjects}

The results of the regression model involving EEG measures are presented in Table 3. There was a significant main effect of $\triangle \mathrm{P} 3 \mathrm{~b}$ such that a larger B- minus A-cue difference (indicating greater use of a proactive strategy) was associated with greater anxiety $(B=.283, p=.003)$. There was also a significant three-way interaction between $\mathrm{BI}, \Delta \mathrm{P} 3 \mathrm{~b}$, and $\Delta \mathrm{N} 2(B=.232, p=.017$; see Figure 2 , panel A). A JohnsonNeyman follow-up test revealed that $\mathrm{BI}$ is significantly associated with greater anxiety $(p<.05)$ specifically when $\Delta P 3 b$ is small (indicating a less proactive strategy; $\Delta \mathrm{P} 3 \mathrm{~b} Z<1$ ) and $\Delta N 2$ is large (i.e., more negative, indicating a more reactive strategy; $\Delta N 2 Z<-.75$; see Figure 2, panel B). 
medRxiv preprint doi: https://doi.org/10.1101/2020.12.01.20242123; this version posted December 2 , 2020. The copyright holder for this preprint (which was not certified by peer review) is the author/funder, who has granted medRxiv a license to display the preprint in perpetuity.

It is made available under a CC-BY-NC-ND 4.0 International license .

BI AND DUAL MECHANISMS OF ANXIETY RISK

\section{Discussion}

The present study tested whether the relations between early BI and adolescent anxiety vary as a function of reactive and proactive control. In light of previous 13-year behavioral findings from this sample indicating that a greater relative reliance on reactive control (compared to proactive control) predicted risk for anxiety among children high in BI (Troller-Renfree et al., 2019), we hypothesized that early BI would be associated with greater anxiety specifically among adolescents using a strategy characterized by low proactive control and high reactive control at age 15 years. Because the behavioral measure of proactive versus reactive control (i.e., $d^{\prime}$ context) is essentially a difference score indicating a participant's relative preference for one strategy versus the other, it was important to use separate neural measures for proactive and reactive control in order to test whether past behavioral findings were driven mainly by proactive control, by reactive control, or by both. Using the cue-locked $\triangle \mathrm{P} 3 \mathrm{~b}$ as a measure of proactive control and the probe-locked $\Delta \mathrm{N} 2$ as a measure of reactive control, we found that the relations between early $\mathrm{BI}$ and greater anxiety are only significant among adolescents who use a cognitive control strategy characterized by low proactive control (i.e., $\Delta \mathrm{P} 3 \mathrm{~b}$ is smaller/less positive) and high reactive control (i.e., $\Delta \mathrm{N} 2$ is larger/more negative). However, we did not replicate the 13-year behavioral findings at this 15-year assessment, possibly due to differences in task parameters or due to developmental changes in cognitive control and anxiety. Nevertheless, ERP results indicated that both proactive and reactive control processes influence the relations amongst $\mathrm{BI}$ and anxiety.

The present findings support an emerging view of Bl's neurophysiological profile (Buzzell et al., 2018; Fox et al., under review; Henderson et al., 2015; Henderson \& Wilson, 2017). According to this view, although $\mathrm{BI}$ is associated with heightened detection of salient stimuli (e.g., threatening faces, novel auditory tones), some children with BI learn to moderate their responses to novelty or unfamiliarity over time via increased proactive control. This increased proactive control helps the child recover their goal-oriented attention and reduces the length of time that attention is shifted toward a 
medRxiv preprint doi: https://doi.org/10.1101/2020.12.01.20242123; this version posted December 2, 2020. The copyright holder for this preprint (which was not certified by peer review) is the author/funder, who has granted medRxiv a license to display the preprint in perpetuity. It is made available under a CC-BY-NC-ND 4.0 International license .

salient stimulus when it occurs, thereby reducing risk for anxiety. In contrast to proactive control, reactive control maintains attention toward the salient stimulus (thus, increasing risk for anxiety) in order to resolve conflict or support quick and reflexive corrections to behavior. Together, these two types of control influence the child's ability to fluidly respond to salient stimuli in goal-directed contexts; yet, they have distinguishable associations with anxiety.

In addition to the BI pathway described above, results revealed that adolescents with a more positive $\Delta \mathrm{P} 3 \mathrm{~b}$, which we interpreted as indicating a highly proactive strategy, tended to have greater total anxiety. Importantly, this $\triangle \mathrm{P} 3 \mathrm{~b}$ effect was independent of $\mathrm{BI}$ and there was no significant $\Delta \mathrm{P} 3 \mathrm{~b} * \mathrm{BI}$ interaction, indicating that greater reliance on proactive control may reflect a general risk pathway for anxiety. This raises the question, however, of how proactive control can be a risk factor for anxiety while also being protective against anxiety among youth high in BI. One possibility is that whereas a certain minimum level of proactive control may be needed for children with $\mathrm{BI}$ to avoid being unduly disrupted by salient stimuli, an excessive, over-reliance on proactive control might reduce children's ability to flexibly respond to salient events as they arise, regardless of BI status. In other words, proactive control may be protective when salience detection is elevated (as in the case of $\mathrm{BI}$ ), but instead increases risk for anxiety when salience detection is at lower levels. In order to test this hypothesis, future work would benefit from the inclusion of a salience detection measure (e.g., a measure of threat bias from a dotprobe task) in addition to measures of proactive and reactive control.

Another possibility is that the etiological pathway to anxiety associated with proactive control and the pathway to anxiety associated with $\mathrm{BI}$ each give rise to a different subtype of anxiety. Although $\mathrm{BI}$ is a strong risk factor for the development of future anxiety (Chronis-Tuscano et al., 2009; Clauss \& Blackford, 2012), it is important to note that many children without a history of BI also go on to develop anxiety difficulties later in life. Thus, there may be multiple pathways through which a child can develop problems with anxiety, and it could be the case that each pathway/subtype is associated with a different 
medRxiv preprint doi: https://doi.org/10.1101/2020.12.01.20242123; this version posted December 2, 2020. The copyright holder for this preprint (which was not certified by peer review) is the author/funder, who has granted medRxiv a license to display the preprint in perpetuity. It is made available under a CC-BY-NC-ND 4.0 International license .

profile of cognitive control dynamics. Previous neuroimaging work has demonstrated that cognitivecontrol-related neural activity differentiates BI and non-BI anxious youth (Abend et al., 2020; Smith et al., 2019), suggesting that cognitive control could serve as a potential criterion for defining anxious subtypes. However, the present study is the first to characterize how proactive and reactive control each uniquely relate to these pathways/subtypes.

In addition to having implications for the conceptualization of heterogeneous anxiety, the present findings may also inform anxiety intervention efforts. If it is the case that proactive control protects youth with $\mathrm{BI}$ against anxiety, proactive control may be a promising intervention target for this subgroup of children. Although interventions targeting salience detection (e.g., attention bias modification) (MacLeod \& Mathews, 2012) are likely appropriate for all anxious youth, children with BI may respond better to an intervention aiming instead to enhance proactive control, as heightened salience detection is a core feature of BI (Fox et al., 2005; Kagan et al., 1984) and thus may be less malleable for this group than is proactive control.

Critically, the present study does not allow for causal inferences in the associations between cognitive control processes and anxiety, in part due to the lack of temporal separation (i.e., with the exception of $\mathrm{Bl}$, which was assessed during toddlerhood, all other measures were assessed at the same 15-year time point) but also due to the lack of random assignment. Moreover, the present longitudinal sample was oversampled for extreme levels of motor and positive or negative reactivity during toddlerhood (Hane et al., 2008), possibly limiting generalizability; however, this oversampling approach was necessary in order to achieve a sufficient number of children with $\mathrm{Bl}$, which is seen in approximately $10-15 \%$ of young children (Fox et al., 2005). Nevertheless, in addition to benefitting from early laboratory assessment of early BI (as opposed to relying on retrospective report), the present study was aided by a relatively large sample size which provided sufficient statistical power to detect the interaction between $\mathrm{BI}$, proactive control, and reactive control. 
medRxiv preprint doi: https://doi.org/10.1101/2020.12.01.20242123; this version posted December 2, 2020. The copyright holder for this preprint

(which was not certified by peer review) is the author/funder, who has granted medRxiv a license to display the preprint in perpetuity.

It is made available under a CC-BY-NC-ND 4.0 International license.

BI AND DUAL MECHANISMS OF ANXIETY RISK

In summary, the present findings suggest that early $\mathrm{Bl}$ is associated with elevated anxiety symptoms among adolescents who rely more on reactive control strategies (as indicated by a larger $\Delta \mathrm{N} 2$ ) and less on proactive strategies (as indicated by a smaller $\Delta \mathrm{P} 3 \mathrm{~b}$ ), possibly indicating that, among children with early $\mathrm{BI}$, proactive control is protective against anxiety whereas reactive control increases anxiety risk. In addition, results revealed a non-BI pathway to anxiety involving elevated proactive control, suggesting that proactive control distinguishes pathways to anxiety occurring only with $\mathrm{BI}$ from that occurring regardless of BI level.

Acknowledgements: This research was supported by the National Institute of Mental Health, Grand/Award Number: U01MH093349 (to N. A. F.).

Correspondence: Emilio A. Valadez (e-mail: evaladez@umd.edu), Department of Human Development and Quantitative Methodology, University of Maryland, 3942 Campus Dr, College Park, MD 20742. 
medRxiv preprint doi: https://doi.org/10.1101/2020.12.01.20242123; this version posted December 2, 2020. The copyright holder for this preprint (which was not certified by peer review) is the author/funder, who has granted medRxiv a license to display the preprint in perpetuity. It is made available under a CC-BY-NC-ND 4.0 International license .

\section{Key Points}

- Behaviorally inhibited (BI) temperament is a strong predictor of anxiety problems later in life, but this association is moderated by cognitive control factors.

- By separating proactive and reactive control processes using EEG, the present study is the first to characterize how proactive and reactive control uniquely relate to pathways toward anxiety risk.

- Findings suggest that BI relates to risk for anxiety specifically among adolescents who rely less on proactive strategies and more on reactive control strategies.

- Results also revealed that proactive control differentiates a BI-related etiological pathway to anxiety from a more general pathway to anxiety occurring regardless of BI level.

- Overall, findings indicate that cognitive control could serve as a potential criterion for defining anxious subtypes. 
medRxiv preprint doi: https://doi.org/10.1101/2020.12.01.20242123; this version posted December 2, 2020. The copyright holder for this preprint

(which was not certified by peer review) is the author/funder, who has granted medRxiv a license to display the preprint in perpetuity.

It is made available under a CC-BY-NC-ND 4.0 International license .

BI AND DUAL MECHANISMS OF ANXIETY RISK

References

Abend, R., Swetlitz, C., White, L. K., Shechner, T., Bar-Haim, Y., Filippi, C., Kircanski, K., Haller, S. P., Benson, B. E., Chen, G., Leibenluft, E., Fox, N. A., \& Pine, D. S. (2020). Levels of early-childhood behavioral inhibition predict distinct neurodevelopmental pathways to pediatric anxiety. Psychological Medicine, 50(1), 96-106. https://doi.org/10.1017/\$0033291718003999

Barch, D. M., Braver, T. S., Nystrom, L. E., Forman, S. D., Noll, D. C., \& Cohen, J. D. (1997). Dissociating working memory from task difficulty in human prefrontal cortex. Neuropsychologia, 35(10), 1373-1380. https://doi.org/10.1016/s0028-3932(97)00072-9

Bowers, M. E., Reider, L. B., Morales, S., Buzzell, G. A., Miller, N., Troller-Renfree, S. V., Pine, D. S., Henderson, H. A., \& Fox, N. A. (2020). Differences in parent and child report on the screen for child anxiety-related emotional disorders (SCARED): Implications for investigations of social anxiety in adolescents. Journal of Abnormal Child Psychology, 48(4), 561-571. https://doi.org/10.1007/s10802-019-00609-3

Braver, T. S. (2012). The variable nature of cognitive control: A dual mechanisms framework. Trends in Cognitive Sciences, 16(2), 106-113. https://doi.org/10.1016/j.tics.2011.12.010

Buzzell, G. A., Troller-Renfree, S. V., Barker, T. V., Bowman, L. C., Chronis-Tuscano, A., Henderson, H. A., Kagan, J., Pine, D. S., \& Fox, N. A. (2017). A neurobehavioral mechanism linking behaviorally inhibited temperament and later adolescent social anxiety. Journal of the American Academy of Child \& Adolescent Psychiatry, 56(12), 1097-1105. https://doi.org/10.1016/j.jaac.2017.10.007

Buzzell, G. A., Troller-Renfree, S. V., Morales, S., \& Fox, N. A. (2018). Relations between behavioral inhibition, cognitive control, and anxiety: Novel insights provided by parsing subdomains of cognitive control. In K. Pérez-Edgar \& N. A. Fox (Eds.), Behavioral Inhibition: Integrating Theory, Research, and Clinical Perspectives (pp. 213-235). Springer International Publishing. https://doi.org/10.1007/978-3-319-98077-5_10 
medRxiv preprint doi: https://doi.org/10.1101/2020.12.01.20242123; this version posted December 2, 2020. The copyright holder for this preprint

(which was not certified by peer review) is the author/funder, who has granted medRxiv a license to display the preprint in perpetuity.

It is made available under a CC-BY-NC-ND 4.0 International license .

BI AND DUAL MECHANISMS OF ANXIETY RISK

Calkins, S. D., Fox, N. A., \& Marshall, T. R. (1996). Behavioral and physiological antecedents of inhibited and uninhibited behavior. Child Dev, 67(2), 523-540.

https://www.ncbi.nlm.nih.gov/pubmed/8625726

Chevalier, N., Martis, S. B., Curran, T., \& Munakata, Y. (2015). Metacognitive processes in executive control development: The case of reactive and proactive control. Journal of Cognitive Neuroscience, 27(6), 1125-1136. https://doi.org/10.1162/jocn_a_00782

Chronis-Tuscano, A., Degnan, K. A., Pine, D. S., Perez-Edgar, K., Henderson, H. A., Diaz, Y., Raggi, V. L., \& Fox, N. A. (2009). Stable early maternal report of behavioral inhibition predicts lifetime social anxiety disorder in adolescence. Journal of the American Academy of Child \& Adolescent Psychiatry, 48(9), 928-935. https://doi.org/10.1097/CHI.0b013e3181ae09df

Clauss, J. A., \& Blackford, J. U. (2012). Behavioral Inhibition and Risk for Developing Social Anxiety Disorder: A Meta-Analytic Study. Journal of the American Academy of Child \& Adolescent Psychiatry, 51(10), 1066-1075.e1. https://doi.org/10.1016/j.jaac.2012.08.002

Clayson, P. E., Baldwin, S. A., \& Larson, M. J. (2013). How does noise affect amplitude and latency measurement of event-related potentials (ERPs)? A methodological critique and simulation study. Psychophysiology, 50(2), 174-186. https://doi.org/10.1111/psyp.12001

Cohen, J. D., Barch, D. M., Carter, C., \& Servan-Schreiber, D. (1999). Context-processing deficits in schizophrenia: Converging evidence from three theoretically motivated cognitive tasks. J Abnorm Psychol, 108(1), 120-133. https://doi.org/10.1037//0021-843x.108.1.120

Debnath, R., Buzzell, G. A., Morales, S., Bowers, M. E., Leach, S. C., \& Fox, N. A. (2020). The Maryland analysis of developmental EEG (MADE) pipeline. Psychophysiology, 57(6), e13580. https://doi.org/10.1111/psyp.13580 
medRxiv preprint doi: https://doi.org/10.1101/2020.12.01.20242123; this version posted December 2, 2020. The copyright holder for this preprint

(which was not certified by peer review) is the author/funder, who has granted medRxiv a license to display the preprint in perpetuity.

It is made available under a CC-BY-NC-ND 4.0 International license .

BI AND DUAL MECHANISMS OF ANXIETY RISK

Delorme, A., \& Makeig, S. (2004). EEGLAB: An open source toolbox for analysis of single-trial EEG dynamics including independent component analysis. Journal of Neuroscience Methods, 134(1), 9-21. https://doi.org/10.1016/j.jneumeth.2003.10.009

Fox, N. A., Buzzell, G. A., Morales, S., Valadez, E. A., Wilson, M. L. J. G., \& Henderson, H. A. (under review). Understanding the Emergence of Social Anxiety in Children with Behavioral Inhibition.

Fox, N. A., Henderson, H. A., Marshall, P. J., Nichols, K. E., \& Ghera, M. M. (2005). Behavioral inhibition: Linking biology and behavior within a developmental framework. Annual Review of Psychology, 56(1), 235-262. https://doi.org/10.1146/annurev.psych.55.090902.141532

Fox, N. A., Henderson, H. A., Rubin, K. H., Calkins, S. D., \& Schmidt, L. A. (2001). Continuity and discontinuity of behavioral inhibition and exuberance: Psychophysiological and behavioral influences across the first four years of life. Child Dev, 72(1), 1-21.

https://doi.org/10.1111/1467-8624.00262

Fox, N. A., \& Pine, D. S. (2012). Temperament and the emergence of anxiety disorders. Journal of the American Academy of Child and Adolescent Psychiatry, 51(2), 125-128. PubMed. https://doi.org/10.1016/j.jaac.2011.10.006

Gladstone, G. L., Parker, G. B., Mitchell, P. B., Wilhelm, K. A., \& Malhi, G. S. (2005). Relationship between self-reported childhood behavioral inhibition and lifetime anxiety disorders in a clinical sample. Depression and Anxiety, 22(3), 103-113. https://doi.org/10.1002/da.20082

Gonthier, C., Braver, T. S., \& Bugg, J. M. (2016). Dissociating proactive and reactive control in the Stroop task. Memory \& Cognition, 44(5), 778-788. https://doi.org/10.3758/s13421-016-0591-1

Hane, A., Cheah, C., Rubin, K., \& Fox, N. A. (2008). The role of maternal behavior in the relation between shyness and social reticence in early childhood and social withdrawal in middle childhood. Social Development, 17(4), 795-811. https://doi.org/10.1111/j.1467-9507.2008.00481.x 
medRxiv preprint doi: https://doi.org/10.1101/2020.12.01.20242123; this version posted December 2, 2020. The copyright holder for this preprint

(which was not certified by peer review) is the author/funder, who has granted medRxiv a license to display the preprint in perpetuity.

It is made available under a CC-BY-NC-ND 4.0 International license .

Henderson, H. A. (2010). Electrophysiological correlates of cognitive control and the regulation of shyness in children. Developmental Neuropsychology, 35(2), 177-193. https://doi.org/10.1080/87565640903526538

Henderson, H. A., Pine, D. S., \& Fox, N. A. (2015). Behavioral inhibition and developmental risk: A dualprocessing perspective. Neuropsychopharmacology, 40(1), 207-224. https://doi.org/10.1038/npp.2014.189

Henderson, H. A., \& Wilson, M. J. G. (2017). Attention processes underlying risk and resilience in behaviorally inhibited children. Current Behavioral Neuroscience Reports, 4(2), 99-106. https://doi.org/10.1007/s40473-017-0111-z

Johnson, P. O., \& Neyman, J. (1936). Tests of certain linear hypotheses and their application to some educational problems. Statistical Research Memoirs, 1, 57-93.

Kagan, J., Reznick, J. S., Clarke, C., Snidman, N., \& Garcia-Coll, C. (1984). Behavioral inhibition to the unfamiliar. Child Development, 55(6), 2212-2225. JSTOR. https://doi.org/10.2307/1129793

Lahat, A., Lamm, C., Chronis-Tuscano, A., Pine, D., Henderson, H., \& Fox, N. A. (2014). Early behavioral inhibition and increased error monitoring predict later social phobia symptoms in childhood. Journal of the American Academy of Child and Adolescent Psychiatry, 53(4), 447-455. https://doi.org/10.1016/j.jaac.2013.12.019

Lamm, C., Pine, D. S., \& Fox, N. A. (2013). Impact of negative affectively charged stimuli and response style on cognitive-control-related neural activation: An ERP study. Brain and Cognition, 83(2), 234-243. https://doi.org/10.1016/j.bandc.2013.07.012

Lamm, C., Walker, O. L., Degnan, K. A., Henderson, H. A., Pine, D. S., McDermott, J. M., \& Fox, N. A. (2014). Cognitive control moderates early childhood temperament in predicting social behavior in 7-year-old children: An ERP study. Developmental Science, 17(5), 667-681.

https://doi.org/10.1111/desc.12158 
medRxiv preprint doi: https://doi.org/10.1101/2020.12.01.20242123; this version posted December 2, 2020. The copyright holder for this preprint

(which was not certified by peer review) is the author/funder, who has granted medRxiv a license to display the preprint in perpetuity.

It is made available under a CC-BY-NC-ND 4.0 International license .

BI AND DUAL MECHANISMS OF ANXIETY RISK

Leach, S. C., Morales, S., Bowers, M. E., Buzzell, G. A., Debnath, R., Beall, D., \& Fox, N. A. (2020).

Adjusting ADJUST: Optimizing the ADJUST algorithm for pediatric data using geodesic nets. Psychophysiology, 57(8), e13566.

Long, J. A. (2019). Interactions: Comprehensive, user-friendly toolkit for probing interactions (1.1.0) [Computer software]. https://cran.r-project.org/package=interactions

Lucenet, J., \& Blaye, A. (2014). Age-related changes in the temporal dynamics of executive control: A study in 5- and 6-year-old children. Frontiers in Psychology, 5, 831. https://doi.org/10.3389/fpsyg.2014.00831

MacLeod, C., \& Mathews, A. (2012). Cognitive bias modification approaches to anxiety. Annual Review of Clinical Psychology, 8(1), 189-217. https://doi.org/10.1146/annurev-clinpsy-032511-143052

McDermott, J. M., Perez-Edgar, K., Henderson, H. A., Chronis-Tuscano, A., Pine, D. S., \& Fox, N. A. (2009). A history of childhood behavioral inhibition and enhanced response monitoring in adolescence are linked to clinical anxiety. Biological Psychiatry, 65(5), 445-448. PubMed. https://doi.org/10.1016/j.biopsych.2008.10.043

Mognon, A., Jovicich, J., Bruzzone, L., \& Buiatti, M. (2011). ADJUST: An automatic EEG artifact detector based on the joint use of spatial and temporal features. Psychophysiology, 48(2), 229-240. https://doi.org/10.1111/j.1469-8986.2010.01061.x

Monga, S., Birmaher, B., Chiappetta, L., Brent, D., Kaufman, J., Bridge, J., \& Cully, M. (2000). Screen for child anxiety-related emotional disorders (SCARED): Convergent and divergent validity. Depression and Anxiety, 12(2), 85-91. https://doi.org/10.1002/1520-6394(2000)12:2<85::AIDDA4>3.0.CO;2-2

Nolan, H., Whelan, R., \& Reilly, R. B. (2010). FASTER: Fully automated statistical thresholding for EEG artifact rejection. Journal of Neuroscience Methods, 192(1), 152-162.

https://doi.org/10.1016/j.jneumeth.2010.07.015 
medRxiv preprint doi: https://doi.org/10.1101/2020.12.01.20242123; this version posted December 2, 2020. The copyright holder for this preprint

(which was not certified by peer review) is the author/funder, who has granted medRxiv a license to display the preprint in perpetuity.

It is made available under a CC-BY-NC-ND 4.0 International license .

BI AND DUAL MECHANISMS OF ANXIETY RISK

Oostenveld, R., Fries, P., Maris, E., \& Schoffelen, J.-M. (2010). FieldTrip: Open source software for advanced analysis of MEG, EEG, and invasive electrophysiological data. Computational Intelligence and Neuroscience, 2011, 156869. https://doi.org/10.1155/2011/156869

Reeb-Sutherland, B. C., Vanderwert, R. E., Degnan, K. A., Marshall, P. J., Pérez-Edgar, K., ChronisTuscano, A., Pine, D. S., \& Fox, N. A. (2009). Attention to novelty in behaviorally inhibited adolescents moderates risk for anxiety. Journal of Child Psychology and Psychiatry, 50(11), 1365-1372. https://doi.org/10.1111/j.1469-7610.2009.02170.x

Schwartz, C. E., Snidman, N., \& Kagan, J. (1999). Adolescent social anxiety as an outcome of inhibited temperament in childhood. Journal of the American Academy of Child \& Adolescent Psychiatry, 38(8), 1008-1015. https://doi.org/10.1097/00004583-199908000-00017

Smith, A. R., White, L. K., Leibenluft, E., McGlade, A. L., Heckelman, A. C., Haller, S. P., Buzzell, G. A., Fox, N. A., \& Pine, D. S. (2019). The heterogeneity of anxious phenotypes: Neural responses to errors in treatment-seeking anxious and behaviorally inhibited youths. Journal of the American Academy of Child \& Adolescent Psychiatry, 59(6), 759-769. https://doi.org/10.1016/j.jaac.2019.05.014

Tenke, C. E., \& Kayser, J. (2012). Generator localization by current source density (CSD): Implications of volume conduction and field closure at intracranial and scalp resolutions. Clinical Neurophysiology, 123(12), 2328-2345. https://doi.org/10.1016/j.clinph.2012.06.005

Thorell, L., Bohlin, G., \& Rydell, A.-M. (2004). Two types of inhibitory control: Predictive relations to social functioning. International Journal of Behavioral Development, 28(3), 193-203. https://doi.org/10.1080/01650250344000389

Troller-Renfree, S. V. (2018). The development of cognitive control during childhood: A neurocognitive perspective [University of Maryland, College Park]. https://doi.org/10.13016/M2ZC7RX9B 
medRxiv preprint doi: https://doi.org/10.1101/2020.12.01.20242123; this version posted December 2, 2020. The copyright holder for this preprint

(which was not certified by peer review) is the author/funder, who has granted medRxiv a license to display the preprint in perpetuity.

It is made available under a CC-BY-NC-ND 4.0 International license .

BI AND DUAL MECHANISMS OF ANXIETY RISK

Troller-Renfree, S. V., Buzzell, G. A., Bowers, M. E., Salo, V. C., Forman-Alberti, A., Smith, E., Papp, L. J., McDermott, J. M., Pine, D. S., Henderson, H. A., \& Fox, N. A. (2019). Development of inhibitory control during childhood and its relations to early temperament and later social anxiety: Unique insights provided by latent growth modeling and signal detection theory. Journal of Child Psychology and Psychiatry, 60(6), 622-629. https://doi.org/10.1111/jcpp.13025

Troller-Renfree, S. V., Buzzell, G. A., Pine, D. S., Henderson, H. A., \& Fox, N. A. (2019). Consequences of not planning ahead: Reduced proactive control moderates longitudinal relations between behavioral inhibition and anxiety. Journal of the American Academy of Child \& Adolescent Psychiatry, 58(8), 768-775.e1. https://doi.org/10.1016/j.jaac.2018.06.040

Troller-Renfree, S. V., Buzzell, G., \& Fox, N. A. (2020). Changes in working memory influence the transition from reactive to proactive cognitive control during childhood. Developmental Science. https://doi.org/10.1111/desc.12959

van Wouwe, N. C., Band, G. P., \& Ridderinkhof, K. R. (2011). Positive affect modulates flexibility and evaluative control. J Cogn Neurosci, 23(3), 524-539. https://doi.org/10.1162/jocn.2009.21380

Walker, O., Henderson, H., Degnan, K., Penela, E., \& Fox, N. A. (2014). Associations between behavioral inhibition and children's social problem-solving behavior during social exclusion. Social Development, 23(3), 487-501. https://doi.org/10.1111/sode.12053

White, L. K., McDermott, J. M., Degnan, K. A., Henderson, H. A., \& Fox, N. A. (2011). Behavioral inhibition and anxiety: The moderating roles of inhibitory control and attention shifting. Journal of Abnormal Child Psychology, 39(5), 735-747. https://doi.org/10.1007/s10802-011-9490-x 


\section{Table 1}

\section{Descriptive Statistics and Pearson Correlations}

\begin{tabular}{|c|c|c|c|c|c|c|c|c|c|c|c|c|c|}
\hline Statistic & $N$ & Mean & $S D$ & 1 & 2 & 3 & 4 & 5 & 6 & 7 & 8 & 9 & 10 \\
\hline $\begin{array}{l}\text { 1. Behavioral Inhibition } \\
\text { (Standardized) }\end{array}$ & 134 & -0.01 & 0.75 & & & & & & & & & & \\
\hline $\begin{array}{l}\text { 2. SCARED Total Anxiety } \\
\text { Parent Report }\end{array}$ & 133 & 10.69 & 9.21 & 0.10 & & & & & & & & & \\
\hline $\begin{array}{l}\text { 3. SCARED Total Anxiety } \\
\text { Child Report }\end{array}$ & 125 & 20.48 & 11.75 & 0.03 & $0.54 * * *$ & & & & & & & & \\
\hline $\begin{array}{l}\text { 4. SCARED Total Anxiety } \\
\text { Composite (Z-Scored) }\end{array}$ & 122 & -0.03 & 0.82 & 0.06 & $0.86 * * *$ & $0.88 * * *$ & & & & & & & \\
\hline 5. $d^{\prime}$ Context & 142 & 3.14 & 0.62 & -0.08 & 0.14 & 0.04 & 0.10 & & & & & & \\
\hline $\begin{array}{l}\text { 6. Cue-Locked P3b A } \\
\text { Trials }\left(\mathrm{V} / \mathrm{m}^{2}\right)\end{array}$ & 144 & $1.10 \mathrm{E}-06$ & $6.08 \mathrm{E}-07$ & -0.04 & 0.02 & -0.03 & -0.02 & $0.19 *$ & & & & & \\
\hline $\begin{array}{l}\text { 7. Cue-Locked P3b B } \\
\text { Trials }\left(\mathrm{V} / \mathrm{m}^{2}\right)\end{array}$ & 142 & $1.41 \mathrm{E}-06$ & 7.57E-07 & 0.04 & 0.10 & 0.12 & 0.14 & $0.20 *$ & $0.84 * * *$ & & & & \\
\hline $\begin{array}{l}\text { 8. Cue-Locked P3b B-A } \\
\text { Difference }\left(\mathrm{V} / \mathrm{m}^{2}\right)\end{array}$ & 141 & $3.23 \mathrm{E}-07$ & $4.02 \mathrm{E}-07$ & 0.06 & 0.08 & $0.23 *$ & $0.23 *$ & 0.14 & 0.09 & $0.61^{* * *}$ & & & \\
\hline $\begin{array}{l}\text { 9. Probe-Locked N2 AX } \\
\text { Trials }\left(\mathrm{V} / \mathrm{m}^{2}\right)\end{array}$ & 144 & $-2.00 \mathrm{E}-07$ & $1.66 \mathrm{E}-07$ & -0.07 & 0.01 & 0.07 & 0.03 & -0.10 & $-0.26 * *$ & $-0.30 * * *$ & $-0.18^{*}$ & & \\
\hline $\begin{array}{l}\text { 10. Probe-Locked N2 BX } \\
\text { Trials }\left(\mathrm{V} / \mathrm{m}^{2}\right)\end{array}$ & 142 & $-1.46 \mathrm{E}-07$ & $1.49 \mathrm{E}-07$ & -0.09 & 0.12 & 0.12 & 0.14 & $-0.21^{*}$ & $-0.20^{*}$ & $-0.24 * *$ & -0.10 & $0.38 * * *$ & \\
\hline $\begin{array}{l}\text { 11. Probe-Locked N2 AX- } \\
\text { BX Difference }\left(V / m^{2}\right)\end{array}$ & 141 & $-4.38 \mathrm{E}-08$ & $1.65 \mathrm{E}-07$ & 0.00 & -0.04 & -0.01 & -0.05 & 0.08 & -0.01 & -0.02 & -0.11 & $0.60 * * *$ & $-0.48 * * *$ \\
\hline
\end{tabular}

Note. All values reflect exclusion of outliers (see Data Analytic Strategy). ${ }^{*} p<.05 .{ }^{* *} p<.01 .{ }^{* *} p<.001$. 
medRxiv preprint doi: https://doi.org/10.1101/2020.12.01.20242123; this version posted December 2, 2020. The copyright holder for this preprint (which was not certified by peer review) is the author/funder, who has granted medRxiv a license to display the preprint in perpetuity. It is made available under a CC-BY-NC-ND 4.0 International license .

BI AND DUAL MECHANISMS OF ANXIETY RISK

Table 2

$d^{\prime}$ Context Regression Model Predicting Total Anxiety (Z-Scored)

\begin{tabular}{lccc}
\hline & $\begin{array}{c}\text { Standardized } \\
\text { Peta }\end{array}$ & $95 \% \mathrm{Cl}$ & $p$ \\
\hline (Intercept) & 0.012 & $-0.171-0.195$ & 0.897 \\
Behavioral Inhibition (BI) & 0.043 & $-0.142-0.228$ & 0.644 \\
$d^{\prime}$ Context & 0.111 & $-0.076-0.297$ & 0.242 \\
$\mathrm{BI}^{*} d^{\prime}$ Context interaction & 0.099 & $-0.084-0.281$ & 0.286 \\
\hline Observations & 119 & & \\
$\mathrm{R}^{2} / \mathrm{R}^{2}$ adjusted & $0.021 /-0.005$ & &
\end{tabular}


medRxiv preprint doi: https://doi.org/10.1101/2020.12.01.20242123; this version posted December 2, 2020. The copyright holder for this preprint

(which was not certified by peer review) is the author/funder, who has granted medRxiv a license to display the preprint in perpetuity.

It is made available under a CC-BY-NC-ND 4.0 International license.

BI AND DUAL MECHANISMS OF ANXIETY RISK

Table 3

ERP Regression Model Predicting Total Anxiety (Z-Scored)

\begin{tabular}{lccc}
\hline Predictors & $\begin{array}{c}\text { Standardized } \\
\text { Beta }\end{array}$ & $95 \% \mathrm{Cl}$ & $p$ \\
\hline (Intercept) & -0.007 & $-0.185-0.171$ & 0.935 \\
Behavioral Inhibition (BI) & 0.059 & $-0.121-0.239$ & 0.515 \\
$\Delta \mathrm{N} 2$ & 0.011 & $-0.188-0.210$ & 0.911 \\
$\Delta \mathrm{P} 3 \mathrm{~b}$ & 0.283 & $0.099-0.467$ & 0.003 \\
$\mathrm{BI} * \Delta \mathrm{N} 2$ interaction & -0.117 & $-0.325-0.091$ & 0.267 \\
$\mathrm{BI} * \Delta \mathrm{P} 3 \mathrm{~b}$ interaction & -0.034 & $-0.227-0.159$ & 0.731 \\
$\Delta \mathrm{N} 2 * \Delta \mathrm{P} 3 \mathrm{~b}$ interaction & -0.097 & $-0.284-0.089$ & 0.303 \\
$\mathrm{BI} * \Delta \mathrm{N} 2 * \Delta \mathrm{P} 3 \mathrm{~b}$ interaction & 0.232 & $0.041-0.422$ & 0.017 \\
\hline Observations & 116 & & \\
$\mathrm{R}^{2} / \mathrm{R}^{2}$ adjusted & $0.129 / 0.072$ & &
\end{tabular}




\section{Figure 1}

Grand Average ERP Waveforms
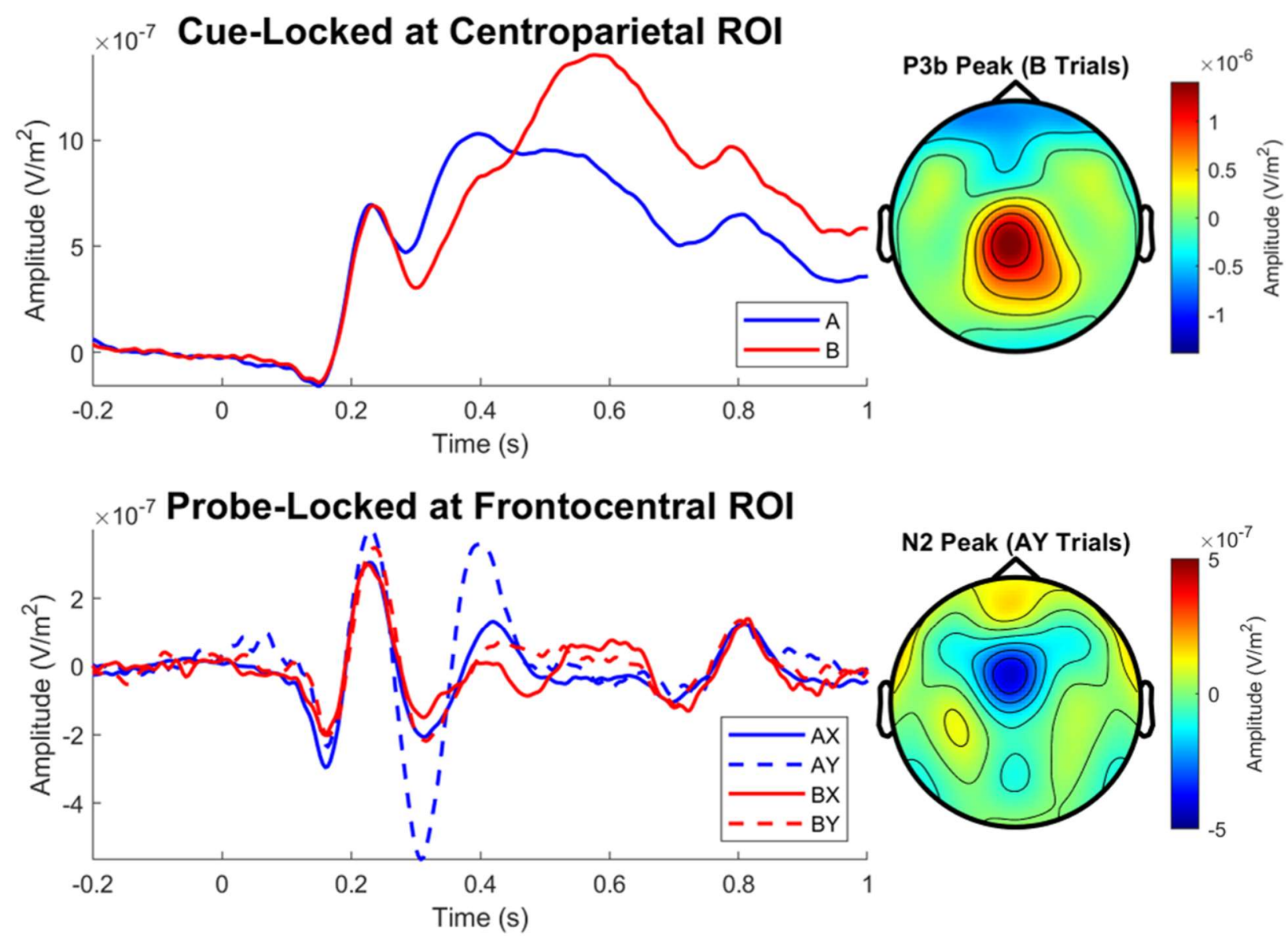

Note. Centroparietal region-of-interest (ROI) included electrodes E31, E54, E55, E79, and E80.

Frontocentral ROI included electrodes E5, E6, E7, E12, E13, E106, and E112. The cue-locked P3b was significantly more positive following B cues than following A cues $(p<.001)$. With regard to the probelocked N2, all trial types significantly differed from each other $(p s<.01)$ with the exception of AX and BY $(p=.654)$. 
medRxiv preprint doi: https://doi.org/10.1101/2020.12.01.20242123; this version posted December 2, 2020. The copyright holder for this preprint (which was not certified by peer review) is the author/funder, who has granted medRxiv a license to display the preprint in perpetuity. It is made available under a CC-BY-NC-ND 4.0 International license .

BI AND DUAL MECHANISMS OF ANXIETY RISK

\section{Figure 2}

Three-Way Interaction and Simple Slopes

\section{A. Three-Way Interaction}

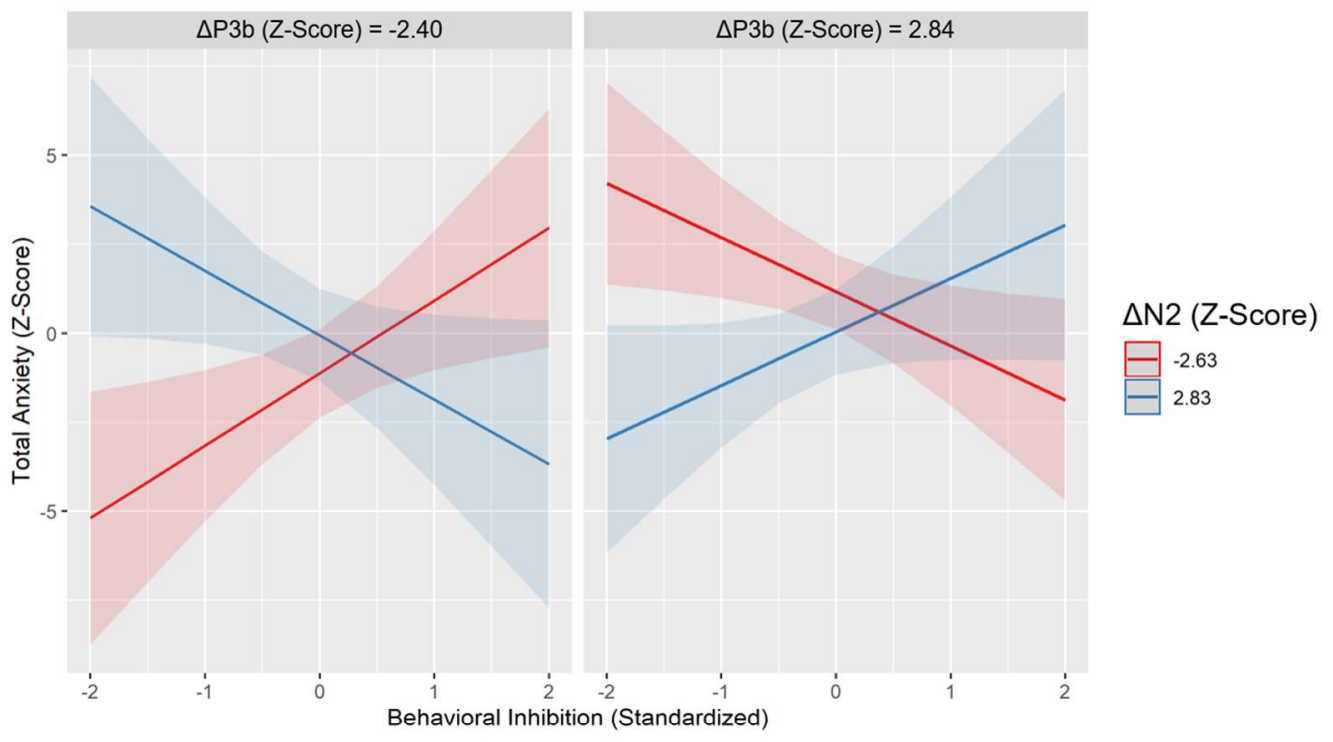

\section{B. Simple Slopes}
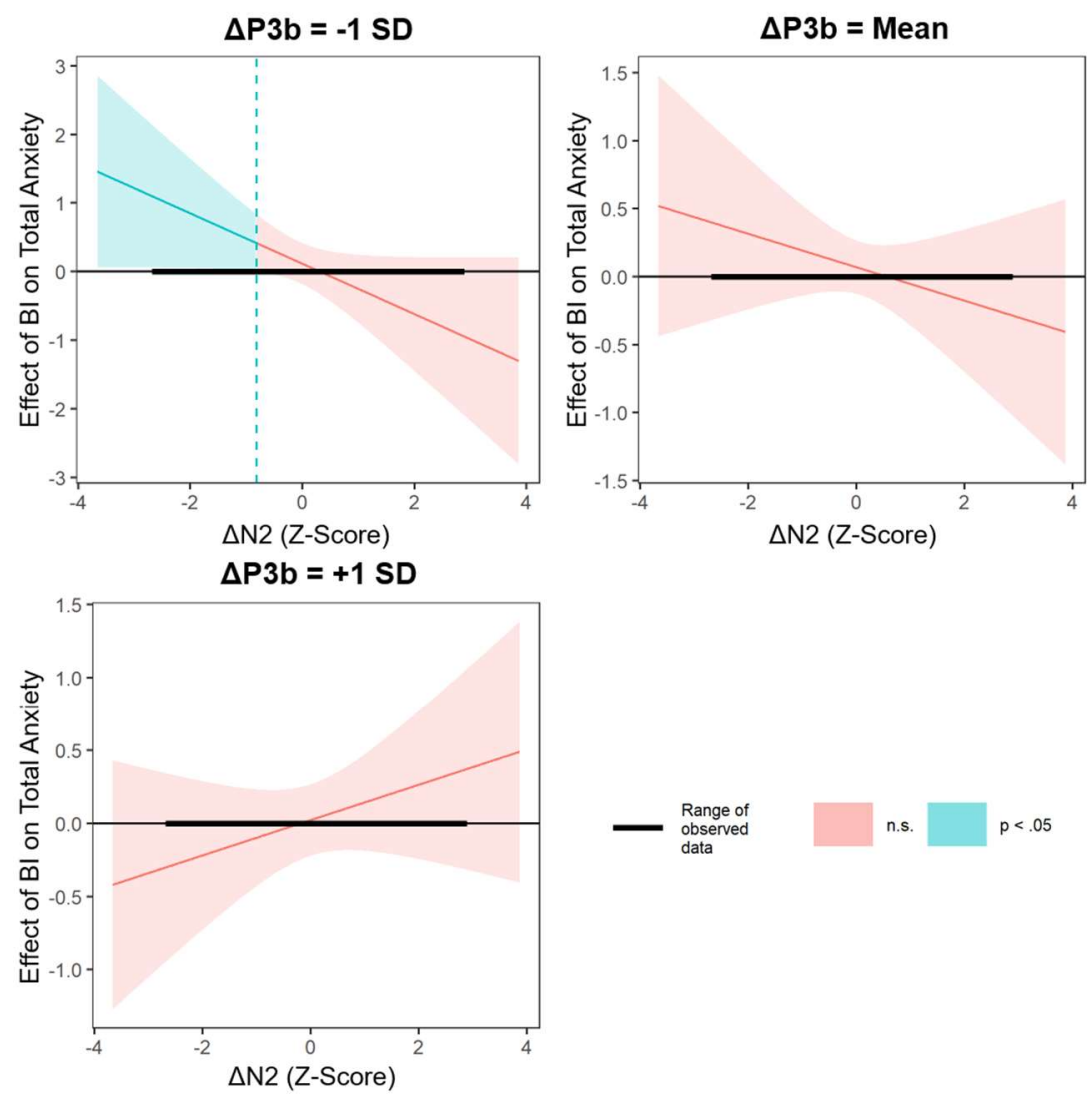
medRxiv preprint doi: https://doi.org/10.1101/2020.12.01.20242123; this version posted December 2, 2020. The copyright holder for this preprint (which was not certified by peer review) is the author/funder, who has granted medRxiv a license to display the preprint in perpetuity. It is made available under a CC-BY-NC-ND 4.0 International license.

Note. A) The three-way interaction between $\mathrm{BI}, \Delta \mathrm{P} 3 \mathrm{~b}$, and $\Delta \mathrm{N} 2\left(p_{\text {interaction }}=.017\right)$, and $\mathrm{B}$ ) JohnsonNeyman plots illustrating results of simple slopes analysis, which revealed that $B \mathrm{I}$ is significantly associated with greater anxiety $(p<.05)$ when $\Delta \mathrm{P} 3 \mathrm{~b}$ is small (i.e., less positive; $\Delta \mathrm{P} 3 \mathrm{~b}$ cutoff: $\mathrm{Z}<1$ ) and $\Delta \mathrm{N} 2$ is large (i.e., more negative; $\Delta \mathrm{N} 2$ cutoff: $\mathrm{Z}<-.75$ ). 